UDC 81'42-139:821.111

DOI https://doi.org/10.32838/2710-4656/2021.4-1/28

Koliesnik I. O.

Kyiv National Linguistic University

\title{
THE MOTIF OF PAIN IN THE FRAMEWORK OF CORPUS ANALYSIS: A NEW PERSPECTIVE
}

This paper outlines possible applications of corpus methodology to analysing the literary motif of pain in British and American modernist prose. As corpus linguistics methods, once thought of exclusively in terms of data collection and analysis, yielded substantial results in stylistic and cognitive poetic research, it has given rise to new vistas in literary text analysis, particularly those of distant reading. Now that a cognitive stylistic/ poetic research does not exclusively rely upon a close text interpretation to determine the way narratives and motifs unfold, the latter can be traced through empirical data too. Such analysis shows that the motif of pain is represented in literary text by key words which are either i) indicative of pain, ii) descriptive of it, or iii) elude to the personages negative and traumatic experience in a particular fictional setting. It appears that the keyness of aforementioned lexical items is higher in the texts where the motif of pain has a prominent plotdriving quality as opposed to those where "pain", its lemmas and words indicative of pain stand to one another in the casual conventional sense rather than the direct one. What is more, the density of the pain keywords grows with the plot development as well as a notable character-developing scenes, therefore successfully accomplishing one of the motif's efficacy factors, that of frequency. Such implementation of the corpus methodology in literary text analysis promises a better understanding of their motifs' structure as well as means of its representation while providing an insight into how a motif can be recognized in larger textual fragments.

Key words: the motif of pain, keyness, cognitive narratology, corpus linguistics, narrative.

Problem statement. The nature of narrative comprehension and the role of language aa well as the reader's experience in such comprehension have evolved a lot with the rise of cognitive narratology $[9 ; 10 ; 13 ; 14 ; 15]$. Given this change, there emerged a need for revising the methodology used to analyze various plot techniques, including that of creating a motif, which can viewed with regards to corpus data [1]. Since cognitive narratology sets a goal of investigating the in-flux-process of narrative comprehension $[15$, p. $32-45]$, the linguistic means providing the backdrop for the narrative have received an extra attention too. Recent works on the reader's narrative meaning-making capacity in terms of corpus stylistics [see, e.g., 29], corpus approaches to metaphor and metonymy analysis $[1$, p. $60-88]$ as well as a promising study of the relationship between keyness and signals of text structuring highlighted the importance of corpus analysis in the researcher's methodological toolkit $[27 ; 28 ; 16 ; 20 ; 21]$.

The motif of pain receives a twofold attention in the above context: i) the disorienting experience of pain has already provoked a plethora of research on the ability of language to describe, signal and categorize pain, with a corpus analysis playing a significant role in it [26]; ii) as a motif is a stock device the efficacy of which is achieved through the repetition of its "chunks" that are scattered through the text $[33$, p. 322-323], ensuring the motif's recognition [12], the motif's markers, or rather keywords, can be traced by the corpus-building software. All this propels the idea of visualization of the motif's unfolding in literary text.

Overview of recent achievements and publications. The last two decades set forward studies of the fictional narrative texture, using stylistics $[2 ; 3 ; 4 ; 5 ; 6 ; 7 ; 8]$, corpus linguistics $[24 ; 27 ; 28]$, and lexical patterning $[16 ; 17 ; 18 ; 20 ; 21 ; 22]$, accompanied by the explorations of the textual/ grammatical nature of fictional narratives [29] as well as corpus analysis of metaphors [1]. The latest studies in the area of literally and non-literally narrative [24; 25 ] have set a precedent for the acute interest in what a corpus may provide for text analysis that is not representative of the language as such.

Though plot, action sequence and character developmentareimportantforareader'scomprehension and recognition of a particular motif, lexical patterning $[16,20,21]$ is at heart of the matter. As keyness is linked to the frequency of the chosen lexical items within the analyzed text with an aim to compare their frequency in a reference corpus [27. p. 23-45], 
lexical patterns, according to Michael Hoey [16], depend on repetition across rather than within the studied texts, referred to as "the aboutness of texts" [16, p. 102]. Though, the study of such relations is not pioneering, it is crucial for our research of the motif of pain, where pain keywords display a tendency of having a higher frequency in literary texts with the prominent emphasis upon pain as compared to the other texts, where such a motif is not salient. Interestingly, Nagel Slater's research on the language of pain [26] includes a very similar analysis, however with the focus on contrasting the existing corpus on pain descriptors and indicators with the corpus of the medical staff's and patients' accounts of pain depiction. In doing so the scholar succeeded in showing how different the verbal representations of pain worded first by the medical professionals and then by those who suffered from it were.

Speaking of pain as a literary motif, it is important to note that it was initially entwined with fabula and sujet first by Russian formalists $[34 ; 35 ; 36]$ and later by scholars, who followed into their steps [31]. With a view of the latest investigations of literary motif [33], there is still scarceness in i) contextualizing the motif in terms of cognitive narratology; and ii) finding out how the motif actually develops in literary text via the respective keywords.

The aim of the article is to define the ways corpus analysis can be applied in the motif of pain research by studying concordance plots of two modernist novels where the motif of pain is a significant plot device and tension trigger, "Invisible Man" by Ralph Ellison [1] and "East of Eden" by John Steinbeck [2], in contrast to the corpus of short stories collection by Virginia Woolf [3], where pain is only a fracture of the fictional texture. Our analysis was made possible due to using AntConc corpus software developed by Anthony Laurence [1].

Results and discussion. The roadmap of our research starts with identifying the pain keywords of prime importance. We narrowed our choice to "pain", "hurt" (both a verb and a noun), "blood", and "black", since i) "pain" and "hurt" directly signal presence of pain in the plotline; ii) "blood" provides and image that is related to some damage inflicted upon a flesh, which directly evokes pain experience recognition; iii) "black" has been chosen for the purpose of exemplifying how a word that does not directly or indirectly refer to pain can become its representative keyword. As "pain" keywords are representative of the collocates and clusters within which it can occur, e.g., "pain and noun-word", "pain of noun-word", "noun-word pain", they foster the readers' expectancy of the plot-development and, thus, the motif of pain recognition. Both "hurt" and "blood" are indicative of a negative painful experience, though in different ways: while "hurt" can indicate a direct intent of inflicting or experiencing pain, "blood" creates a visual image of various damage caused to the body that is dangerous or even life-threatening, which in the majority cases sets a scene where from the infliction of pain it can be inferred that a character suffered a painful experience. "Black" illustrates how a colour term can take on a negative meaning with no direct links to "pain", while cognitively displaying symbolic ties with it, as it does in a racial context, e.g. a reoccurring image of "black streets" in "Invisible Man", where "black" is synonymic to "painful", since a lot of heinous violent acts happen there. It was also used to highlight anecdotal occurrence of "black" as an indicator of colour in the other two novels under consideration, while the data received from "Invisible Man" fails to have the same effect in a non-racially centered texts. For instance, as the protagonist of "Invisible Man" assigns objects, places and people around them with "black" as a main descriptor, he simultaneously describes all the violent and hateful, violent acts which are interlinked with "black" as a imminent quality. Thus, one cannot help, but interpret this keyword with a strong negative and traumatic undertone to it. Meanwhile, "black" used in a text that is not focused on a racial segregation does not entail strong negative meaning, "black boots" [2, p. 147].

By learning the density of the mentioned keywords in all three texts, as well as having a direct visual clue of where they are plot-wise, learning whether they overlap or do not, we shall receive a solid data representation of a motif of pain and its development in the given plotlines.

Pain keywords and plot concordance. Figures 1-3 demonstrate the number (117 hits for "pain", 95 hits for "hurt", 130 hits for "blood", which was the highest ranking one, with no hits of "hurt" keyword in the Virginia Woolf short stories collection corpus) and density of concordance hits the keywords "pain", "hurt" and "blood" display exact position of these keywords in the given texts, which allows us to judge their importance to the main story line plot:

For example, "pain" keyword is scattered throughout "East of Eden", however, its density intensifies towards the end, along with "hurt" keyword to depict a detrimental state of affairs in a family that falls apart. Likewise, a "pain" and "hurt" keywords show up the most in in the context of the protagonist's identity crisis in "Invisible Man". "Blood" keyword 


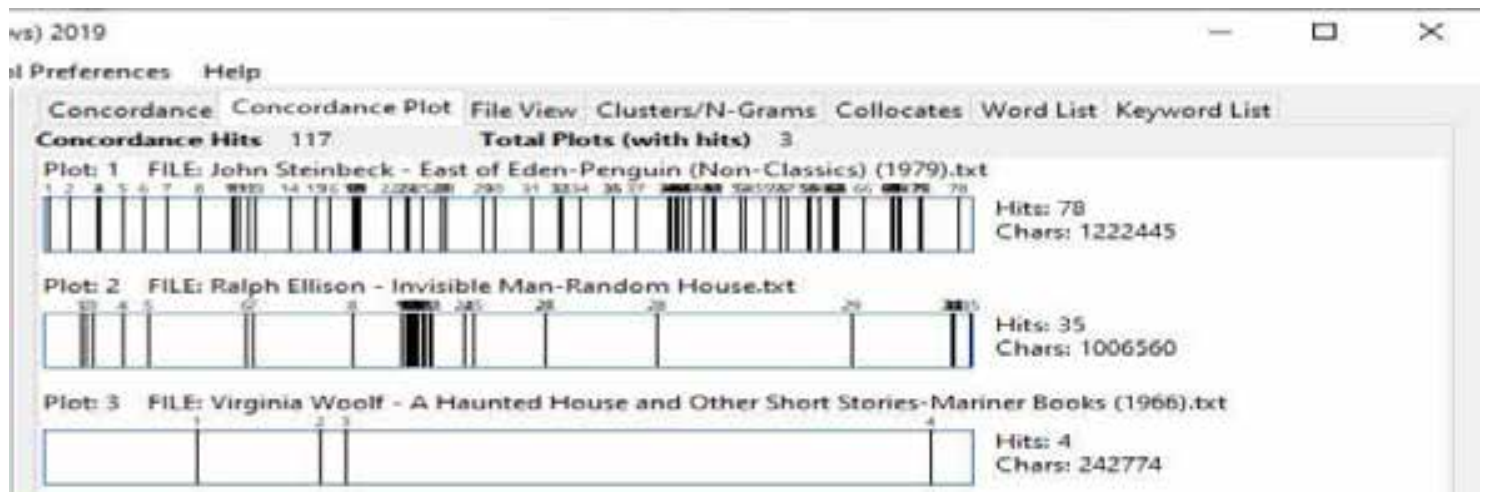

Fig. 1. Concordance hits for "pain" in "East of Eden", "Invisible Man" and Virginia Woolf's short stories collection corpus

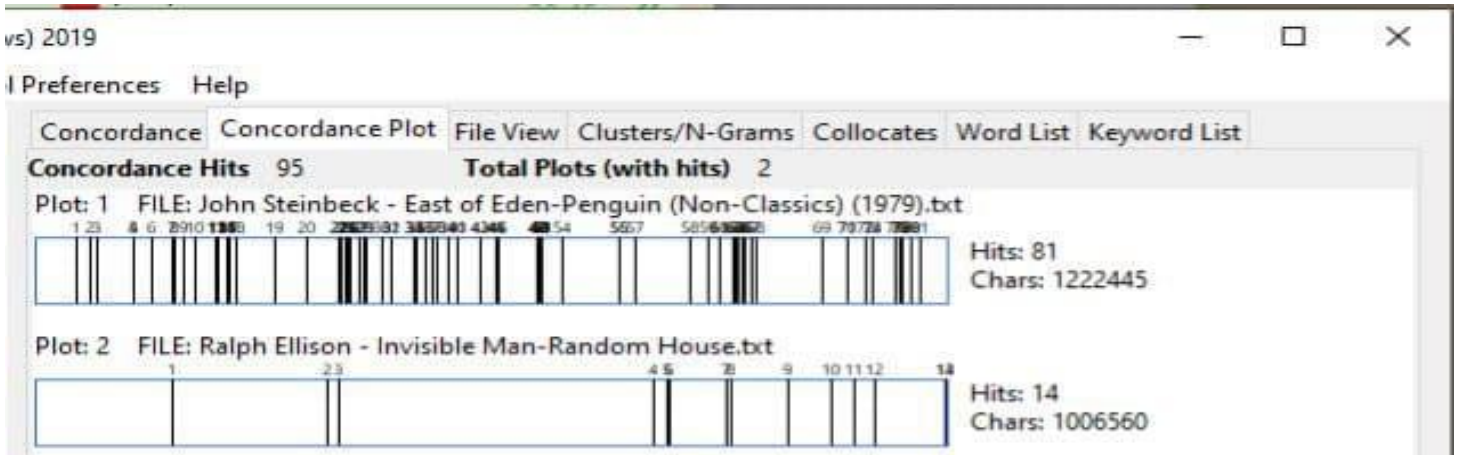

Fig. 2. Concordance hits for "hurt" in "East of Eden" and "Invisible Man"

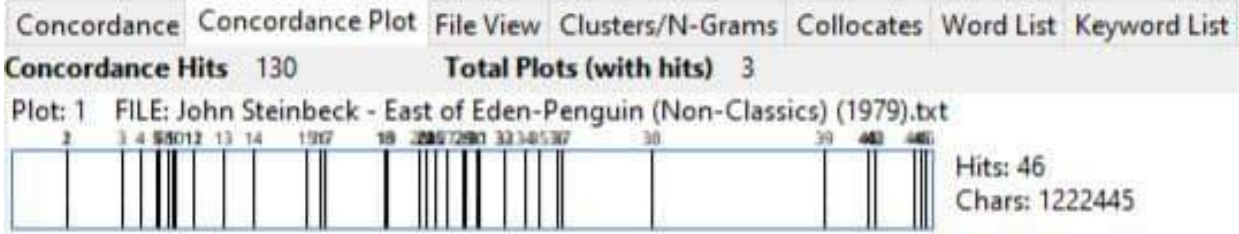

Plot: 2 FILE: Ralph Ellison - Invisible Man-Random House.tot

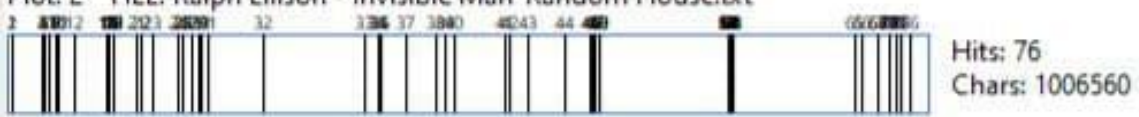

Plot: 3 FILE: Virginia Woolf - A Haunted House and Other Short Stories-Mariner Books (1966),txt

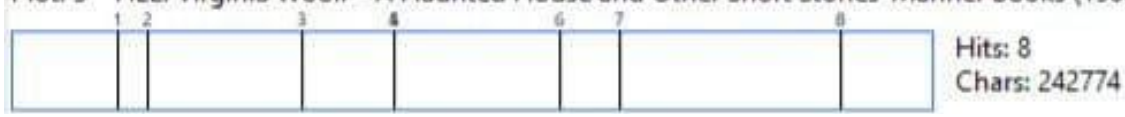

Fig. 3. Concordance hits for "blood" in "East of Eden", "Invisible Man" and Virginia Woolf's short stories collection corpus

appears in the context of violent scenes in both "Invisible Man" and "East of Eden".

Overviewing the data, we may conclude that in a pain-saturated text, like "Invisible Man" and "East of Eden", the personages' traumatic experience is not exclusively portrayed solemnly through "pain" keywords, but rather through the pain-indicating keywords like "hurt", in case of a physical or mental pain or "blood", which appeared exclusively in a context related to physical damage to the bodily tissues. This perpetuates the idea that i) painindicating keywords are usually presented in a close proximity to one another; ii) the density of pain-indicating keywords has a tendency to grow around traumatic and climatic events. Interestingly enough, "hurt" keywords appear the least amount of times in the studied plots. This might be due to the overwhelming nature of pain experience, where 
by large "hurt" indicates the presence of pain, but rarely describes it. In "Invisible Man" as well as in "East of Eden" the focus is zoomed in on the affected character who experiences pain, the nameless protagonist in "Invisible Man" and the main patriarch of the family in "East of Eden", Cyrus Trask, not on the inflictor, which might account for explains the lowest number of hits for "hurt". The high ranking of "blood" keywords is not only associated with the role of violence in the event sequence of the novels, but with its being a triggering factor for pain: blood always entails some sort of tissue damage and immanent discomfort. In the collection of V. Woolf's stories, though, "blood" does not appear in pain-entailing contexts, but displays a conventional figurative meaning, e.g., "blood related" in place of "extended family" or a word "blood" present at the description of a flash image of a scene at the butcher's. Thus, "blood" keyword has a strong indication of a motif of pain present in a text, however, is does not seem to have the same property of its density growing around the character-developing or climactic events, like "pain" or "hurt" possess.

"Pain and" keyword clusters. The highest ranking cluster the keyword "pain" enters in the literary texts under study is that of "pain and", which illustrates the binding nature of a person experience of pain to their other emotions (see Fig. 4):

Generally, clusters shape the readers' expectation as for the linear plot development. In our case study "pain" keywords attach to verbal markers of other negative emotions or emotions which speak of disorientation, such as "pain and sorrow" (line 13), "pain and numbness" (line 9), "pain and puzzlement" (line 11), "pain and despair" (line 3), etc. This tendency signals the complex nature of pain, where the latter often appears in the context of other, less sensationally accurate emotions to colour them. "Pain" keywords can also appear in a cluster with the personal or possessive pronouns. Such occurrence elucidates a deeply personal subjectivity of experiencing pain, as well as an attempt of a character to comprehend a traumatic experience, by interiorizing it.

Uncommon pain-indicating words. The frequency of the pain-related keyword "black" as used in all three textual corpora under study is demonstrated in Fig. 5.

As expected, a racially-tense novel "Invisible Man" by Ralph Ellison has over double the number of "black" hits the other two corpora demonstrate, for the motif of pain is echoed by the plot centred around racism and racial segregation. However, there is an unusually high density of the keyword "black" in "East of Eden". This unexpected finding can be

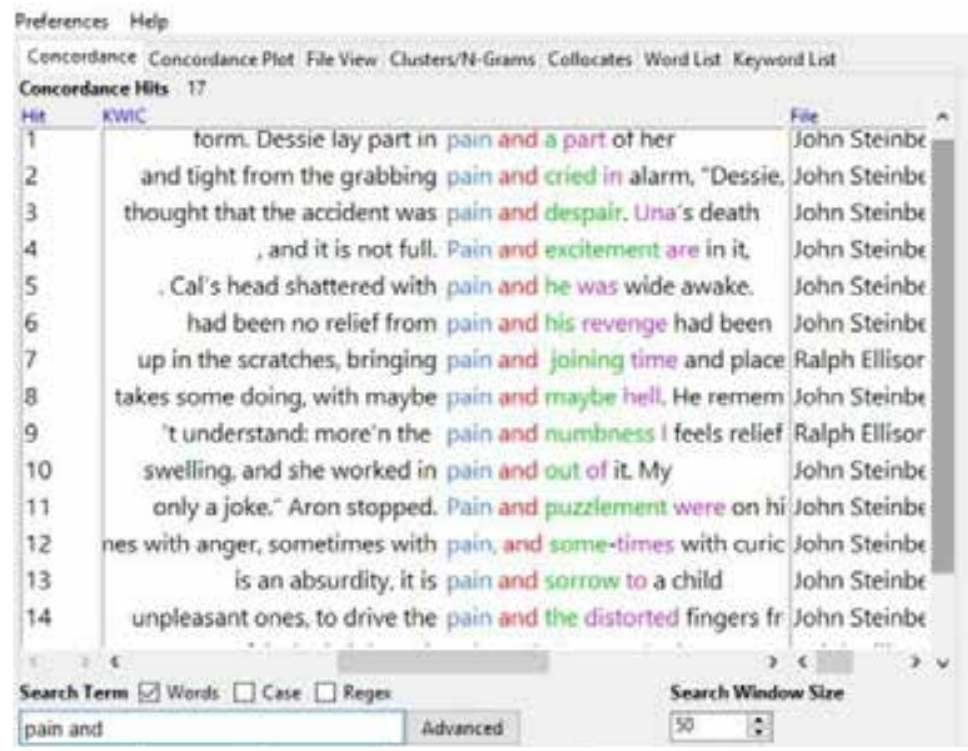

Fig. 4. The list of "pain and" keyword clusters: A file view

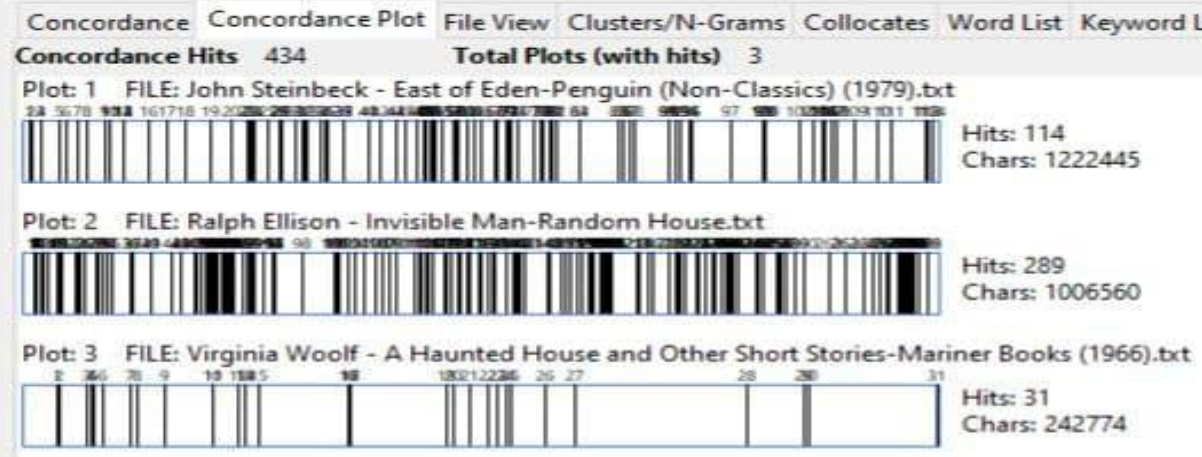

Fig. 5. Concordance hits for "black" in "East of Eden", "Invisible Man" and Virginia Woolf's short stories collection corpus 
attributed to the symbolic nature of pain: Pantola at al.'s paper [27] proves that most individuals associate pain with black or red colours, the former being predominant $[27$, p. 153-160].

Conclusions. The results obtained allow to conclude that the keyness of pain-related lexicon is denser in modernist literary texts where the theme of emotional and physical suffering has a plotdriving significance rather than in those texts where "pain" is used in a conventional way to express the casual response to unfavourable situation or to express dislike or unwiliness to do something. Likewise, the density of pain keywords in the plots under analysis grows as the story and the affected characters' evolved, which in its turn insured their motifs' reiteration, thus fostering the readers' recognition of the respective motif. Thus, corpus analysis strategies help to better understand the motif's structure via non-linear techniques of literary text analysis, along with a better insight of what particular sets of keywords allow readers to identify a present motif in a given plot.

\section{References:}

1. Charteris-Black J. Corpus Approaches to Critical Metaphor Analysis. New York : Palgrave Macmilan, 2004. 263 p.

2. Emmott C. Detective Fiction, Plot Construction, and Reader Manipulation: Rhetorical Control and Cognitive Misdirection in Agatha Christie's Sparkling Cyanide. Language \& Style: In Honour of Mick Short. Houndsmills : Palgrave Macmillan, 2010. P. 328-346.

3. Emmott C. Narrative Comprehension. Oxford : Oxford University Press, 1997. 257 p.

4. Emmott C., Sanford A. Noticing and Not Noticing What's in a Text: Attention, Depth of Processing and Text Interpretation. What's in a Text: Inquiries into the Textual Cornucopia. Cambridge : Cambridge Scholars Press, 2012. P. 6-19.

5. Emmott C., Sanford J., Marc A. Rhetorical Control of Readers' Attention: Stylistic and Psychological Perspectives on Foreground and Background in Narrative. Stories and Minds: Cognitive Approaches to Literary Narrative. Lincoln : University of Nebraska Press, 2013. P. 39-58.

6. Emmott C., Sanford J., Marc A. Scenarios, Role Assumptions, and Character Status: Readers' Expectations and the Manipulation of Attention in Narrative Texts. Characters in Fictional Worlds: Understanding Imaginary Beings in Literature, Film and Other Media. Berlin : de Gruyter, 2010. P. 377-399.

7. Emmott C. Split Selves' in Fiction and in Medical 'Life Stories':From Cognitive Linguistic Theory to Stylistic Practice. Cognitive Stylistics: Language and Cognition in Text Analysis. Philadelphia : Benjamins, 2002. P. 153-181.

8. Emmott C. Sanford J., Lorna M. Towards a theory of reading in the age of cognitive science: Crossdisciplinary perspectives on narrative from stylistics and psychology. Belgian Journal of English Language and Literatures. 2003. P. 17-30.

9. Fludernik M. An Introduction to Narratology. New York : Routledge, 2009. 345 p.

10. Fludernik M. Towards a 'Natural' Narratology. London : Routledge, 2002. 276 p.

11. Forster, E. Aspects of the Novel/ Edward Foster. Harmondsworth: Penguin, 1972, P. 208.

12. Freedman W. The Lierary Motif: a Definition and Evaluation. A Forum on Fiction. 1971. URL: https://doi.org/10.2307/1345147.

13. Herman D. Narrative Theory and the Cognitive Sciences. New York : Routledge, 2003. 396 c.

14. Herman D. Routledge Encyclopaedia of Narrative Theory. New York : Routledge, 2005. $488 \mathrm{c}$.

15. Herman L., Vervaeck B. Handbook of Narrative Analysis. London : University of Nebraska Press, 1994. $428 \mathrm{c}$.

16. Hoey M. On the Surface of Discourse. London : George Allen \& Unwin, 1983. 198 p.

17. Hoey M. 1979. Signalling in Discourse. [Discourse Analysis Monographs 6.] Birmingham : University of Birmingham.

18. Hoey M. Lexical Priming: A New Theory of Words and Language. London : Routledge, 2005. 369 c.

19. Hoey M. Text, Discourse and Corpora. London: Continuum, 2007. 289 p.

20. Hoey M. On the Surface of Discourse. London : George Allen \& Unwin, 1983. 264 p.

21. Hoey M. Patterns of Lexis in Text. Oxford : Oxford University Press, 1991. 236 c.

22. Hoey M. Textual Interaction. London : Routledge, 2001. 308 c.

23. Pier J. On the Semiotic Parameters of Narrative: A Critique of Story and Discourse. What Is Narratology? Questions and Answers Regarding the Status of a Theory. Berlin : de Gruyter, 2003. C. 73-97.

24. Schorer M. Fiction and the 'Matrix of Analogy'. Kenyon. 1949. C. 539-560.

25. Slater N.G. The language of acute pain assessment: a corpus-based critical discourse analysis : дис. ... канд. мед. наук. University of Nottingham, 2015. 240 c.

26. Stubbs M. Three concepts of keyness. Keyness in Texts. Amsterdam : John Benjamins, 2010. C. 240. 
27. Pantoula E., Damigos D., Poulou A., Gouva A. Symbolism of Pain: An Alternative Approach to Pain Means between Patients and Healthy Individuals. International Journal of Caring Sciences. 2017. № 10. C. 153-160.

28. Tognini-Bonelli E. Corpus Linguistics at Work. Amsterdam : John Benjamins, 2001. $230 \mathrm{c}$.

29. Toolan M. Narrative Progressions in the Short Story. A corpus stylistic approach. Amsterdam : John Benjamins, 2009. $240 \mathrm{c}$.

30. Werth P. Text Worlds: Representing Conceptual Space in Discourse. London : Logman, 1999. 302 c.

31. White H. Tropics of Discourse. Baltimore : Johns Hopkins UP, 1978. 190 c.

32. Würzbach N. Motif. Natascha Würzbach. Routledge Encyclopaedia of Narrative Theory. London : Routledge, 2005. C. 322-323.

33. Пропп В. Морфология сказки / Гос. ин-т истории искусств. Ленинград : Academia, 1928. 152 с.

34. Томашевский Б.В. Теория литературы. Поэтика. Москва, 2002.

35. Шкловский В.Б. О теории прозы. Москва, 1983.

\section{List of illustration materials and software:}

1. Anthony, L. AntConc, $3^{\text {rd }}$ version, 2010 [Computer Software]

2. Ellison R. Invisible Man. New York : Random House, 1952. 312 c.

3. Steinbeck J. East of Eden. New York : Viking, 1974. 464 c.

4. Woolf V. A Haunted House and Other Short Stories. Boston : Mariner Books, 2002. 168 c.

\section{КоЛєСНік І. О. МОТИВ БОЛЮ В МЕЖАХ КОРПУСНОГО АНАЛІЗУ: НОВА ПЕРСПЕКТИВА}

У статті окреслено можливості застосування корпусної методології до аналізу художнього мотиву болю у творах американського та британського модернізму. Зважаючи на те, щзо корпусна лінгвістика, яка раніше осмислювалась виключно з позицій збору та аналізу великих за обсягом текстових даних, продемонструвала значні результати у стилістичних та когнітивно-поетологічних дослідженнях, виникли нові перспективи стосовно аналізу художнього тексту, зокрема ті, що стосуються «віддаленого читання» (distant reading). Тепер, коли когнітивно-стилістичний / поетологічний аналіз не спирається виключно на глибинну інтерпретацію тексту (close reading) для визначення того, як розгортаються оповіді і художні мотиви, динаміку останніх можна простежити i на основі емпіричних даних. Проведений у статті аналіз показує, щз мотив болю представлено в художньому тексті ключовими словами, які 1) вказують на біль, 2) описують його або 3) імплікують негативний $і$ травматичний досвід персонажів у конкретних художніх обставинах. Доведено, щзо статус зазначених лексичних одинищь як ключових слів є більш значущим у текстах, де мотив болю має значущість у розвитку сюжету, на відміну від тих текстів, де слово “раіп”, його леми та лексика, що вказує на біль, перебувають між собою скоріше в конвенційних каузальних відношеннях, аніж у безпосередніх. До того ж щільність ключових слів на позначення болю зростає із розгортанням сюжету та появою епізодів, важливих для формування образів персонажів, посилюючи один із головних чинників дієвості мотиву - його частотність. Таке впровадження корпусної методології у традиџійний аналіз художнього тексту сприяе кращому розумінню структури художніх мотивів, засобів їх актуалізації в тексті, а також пояснює, як мотив ідентифікується у більших за обсягом фрагментах тексту.

Ключові слова: мотив болю, статус ключових слів, когнітивна наратологія, корпусна лінгвістика, наратив. 